\title{
Nutrient Requirements for Production of Pycnidia of Botryodiplodia theobromae Pat.
}

\author{
By J. A. EKUNDAYO \\ School of Biological Sciences, University of Lagos, Lagos \\ (Received 3 October 1972; revised I December 1972)
}

INTRODUCTION

Difficulty has been encountered in obtaining sporulation of Botryodiplodia theobromae in culture (Olofinboba, 1967; Ogundana, 1968). Recently Ekundayo \& Haskins (1969) and Alasoadura (1970) demonstrated that the fungus required illumination to produce pycnidia. Moreover, the intensity of its sporulation was influenced by the composition of the culture medium, an aspect considered in more detail below.

\section{METHODS}

An isolate of Botryodiplodia theobromae Pat. from yam (Dioscorea rotundata) was used.

The basal medium consisted of $(\mathrm{g} / \mathrm{l})$ : sucrose, $30 ; \mathrm{K}_{2} \mathrm{HPO}_{4}, \mathrm{I} \cdot 0 ; \mathrm{NaNO}_{3}, 3 \cdot 0 ; \mathrm{MgSO}_{4}$. $7 \mathrm{H}_{2} \mathrm{O}, 0.5 / 1$. 'Analar' grade chemicals were used. Cultures were grown in $250 \mathrm{ml}$ Erlenmeyer flasks, each containing $25 \mathrm{ml}$ medium and incubated at $30{ }^{\circ} \mathrm{C}$ in chambers with 'daylight' fluorescent tubes giving a light intensity of 2 I 53 lux at the culture surface (Ekundayo \& Haskins, I969). The production of pycnidiospores on the various media was assessed after 7 days by removing pycnidia with an inoculating needle and breaking these open in $10 \mathrm{ml}$ distilled water. The pycnidiospore suspension was filtered through three layers of muslin to remove mycelial fragments and the number of spores estimated from counts in a haemocytometer.

\section{RESULTS AND DISCUSSION}

The effects of various combinations of the nutrients in the basal medium on pycnidiospore production are indicated in Table I. Growth was sparse on sucrose alone and no pycnidia were produced. The provision of $\mathrm{NaNO}_{3}$ in addition to sucrose resulted in the production of small pycnidia (90-120 $\mu \mathrm{m}$ in diam.), which showed that a utilizable carbon source and $\mathrm{NO}_{3}{ }^{-}$radical were needed for pycnidium formation. The provision of $\mathrm{Na}_{2} \mathrm{SO}_{4}$ or of $\mathrm{MgSO}_{4} \cdot 7 \mathrm{H}_{2} \mathrm{O}$ in addition to sucrose $+\mathrm{NaNO}_{3}$ did not enhance pycnidium production. The addition of $\mathrm{K}_{2} \mathrm{HPO}_{4}$ to a medium containing sucrose $+\mathrm{NaNO}_{3}$, resulted in production of large globose pycnidia (190 to $230 \mu \mathrm{m}$ in diam.) similar to those which were produced on potato dextrose agar. This indicated that the $\mathrm{K}^{+}$or $\mathrm{HPO}_{4}{ }^{2-}$ radicals or both were needed, in addition to a carbon source and $\mathrm{NO}_{3}{ }^{-}$ion, for the formation of full-size pycnidia. Pycnidiospores from small and large pycnidia were the same in size $\left(32.0\right.$ to $35^{\circ} 5 \times 13^{\circ} \circ$ to $\left.15^{\circ} \mathrm{om}\right)$ but the large pycnidia contained more.

When $\mathrm{K}_{2} \mathrm{HPO}_{4}$ was replaced by $\mathrm{Na}_{2} \mathrm{HPO}_{4}$ as a constituent of the basal medium profuse mycelia growth occurred but no pycnidia were produced. This showed that $\mathrm{K}^{+}$was essential for pycnidium production, and that $\mathrm{Na}^{+}$did not replace $\mathrm{K}^{+}$.

The effect of varying the concentration of $\mathrm{K}^{+}$, supplied as $\mathrm{K}_{2} \mathrm{HPO}_{4}$, was investigated. In these experiments no compensation was made for variations in $\mathrm{HPO}_{4}{ }^{2-}$ concentrations. 
Table I. Effect of various combinations of the components of the basal medium on sporulation of Botryodiplodia theobromae, at $30^{\circ} \mathrm{C}$.

\begin{tabular}{|c|c|c|c|}
\hline Medium & $\begin{array}{c}\text { Size of } \\
\text { pycnidia }\end{array}$ & $\begin{array}{c}\mathrm{I}^{-6} \times \text { spore } \\
\text { density } / \\
\text { culture }\end{array}$ & $\begin{array}{c}\text { Average } \\
\text { spore size } \\
(\mu \mathrm{m})\end{array}$ \\
\hline Sucrose & (None) & 0 & - \\
\hline Sucrose $\mathrm{NaNO}_{3}$ & Tiny* & $19 \cdot 8$ & $34 \times 14$ \\
\hline Sucrose $\mathrm{NaCl}$ & (None) & 0 & - \\
\hline Sucrose $\mathrm{NaNO}_{3}+\mathrm{Na}_{2} \mathrm{SO}_{4}$ & Tiny & $28 \cdot 3$ & $33 \times 14$ \\
\hline Sucrose $\mathrm{NaNO}_{3}+\mathrm{MgSO}_{4} \cdot 7 \mathrm{H}_{2} \mathrm{O}$ & Tiny & $27 \cdot 8$ & $34 \times 15$ \\
\hline Sucrose $\mathrm{NaNO}_{3}+\mathrm{MgSO}_{4} \cdot 7 \mathrm{H}_{2} \mathrm{O}+\mathrm{K}_{3} \mathrm{HPO}_{4}$ & Large $\dagger$ & $26 I \cdot 3$ & $34 \times 14$ \\
\hline Sucrose $\mathrm{NaNO}_{3}+\mathrm{MgSO}_{4} \cdot 7 \mathrm{H}_{2} \mathrm{O}+\mathrm{Na}_{2} \mathrm{HPO}_{4}$ & (None) & 0 & - \\
\hline Sucrose $\mathrm{NaNO}_{3}+\mathrm{K}_{2} \mathrm{HPO}_{4}$ & Large & $258 \cdot 2$ & $34 \times 14$ \\
\hline Sucrose $\mathrm{NaNO}_{3}+\mathrm{MgSO}_{4} \cdot 7 \mathrm{H}_{2} \mathrm{O}+\mathrm{KCl}$ & Large & $328 \cdot 5$ & $34 \times 14$ \\
\hline
\end{tabular}

Increasing $\mathrm{K}^{+}$in the sequence 5, I0, 25, 50, $125 \mathrm{mg} / \mathrm{l}$ resulted in the following, corresponding increases in pycnidiospore production (as $10^{-6} \times$ spore density/culture): $13 \cdot 0,52 \cdot 8,67 \cdot 5$, $206 \cdot \mathrm{I}, 373^{\circ}$. At $25^{\circ}$ and $375 \mathrm{mg} \mathrm{K}+/ 1$ there was a decline in spore density to 225 and 92 respectively and at higher levels of $\mathrm{K}^{+}(500,750$ and $1000 \mathrm{mg} / \mathrm{l})$ no pycnidia were produced. The mean spore size at all $\mathrm{K}^{+}$levels from 5 to $375 \mathrm{mg} / \mathrm{l}$ was $34 \times \mathrm{I} 5 \mu \mathrm{m}$.

In another experiment $\mathrm{K}^{+}$was supplied in $\mathrm{KCl}$; corresponding figures for concentrations over the range 5 to $\mathrm{I} 25 \mathrm{mg} / \mathrm{l}$ were I I $3,42 \cdot 5,55 \cdot 0, \mathrm{I} 82 \cdot 5$ and $280 \cdot 0$ respectively; they rose to 365.0 at $250 \mathrm{mg} \mathrm{K}^{+} / 1$, then declined to 145,15 and 2.5 at 375,500 and $750 \mathrm{mg} \mathrm{K}+/ 1$ respectively, and at $1000 \mathrm{mg} \mathrm{K}+/ 1$ no pycnidia were produced. Since there was no source of phosphate in this experiment, the slightly lower response to $\mathrm{K}^{+}$concentration might either have been the result of phosphate deficiency in the medium or due to $\mathrm{pH}$, which would have tended to be higher with $\mathrm{K}_{2} \mathrm{HPO}_{4}$.

\section{REFERENCES}

Alasoadura, S. O. (I97I). Culture studies on Botryodiplodia theobromae Pat. Mycopathologia et mycologia applicata 42, 153-160.

Ekundayo, J. A. \& Haskins, R. H. (1969). Pycnidium production by Botryodiplodia theobromae I. The relation of light to the induction of pycnidia. Canadian Journal of Botany 47, I153-I I56.

Ogundana, S. K. (1968). Physiological studies on soft rot of yams in storage. M.Sc. Thesis, University of Lagos, Nigeria.

Olofinboba, M. O. (1967). Botryodiplodia blue-stain of wood. Ph.D. Thesis, University of Ibadan, Nigeria. 